Academic Platform Journal of Engineering and Science

\title{
Akdeniz Kıyılarında Ekstrem Nemli Ve Kurak Mevsimlerin Dağılımı (1967-2016)
}

\author{
${ }^{* 1}$ Mehmet Ali Çelik \\ ${ }^{1}$ Kilis 7 Aralık Üniversitesi, Fen- Edebiyat Fakültesi, mehmetalicelikk@gmail.com \\ Research Paper \\ Received Date: 13.02 .2018 \\ Accepted Date: 28.09 .2018
}

$\ddot{O} z$

İklim değişikliği, iklim koşullarının uzun yıllar boyunca ortalama durumdan sapması olarak tanımlanmaktadır. Birçok çalışma iklim değişikliği ile birlikte ekstrem hava olaylarında artış yaşanacağını bildirmektedir. Türkiye'de iklim değişikliğinden en fazla etkilenecek bölgelerden birisi Akdeniz Kıyılarıdır. Bu bağlamda iklim değişikliği bakımından hassas konumda bulunan Türkiye'nin Akdeniz Kıyılarında ekstrem iklim dönemlerinin tespit edilmesi ve gerekli tedbirlerin alınması önemlidir. Bu çalışmada 1967-2016 yıllarını kapsayan son 50 yıllık süreçte mevsimlik SPI kuraklık analizleri yapılmıştır. Çalışmamızda, Akdeniz Kıyılarında yer alan 15 adet meteoroloji istasyonuna ait veriler kullanılmıştır. Elde edilen bulgular, Akdeniz Kıyılarında ekstrem iklim koşullarının sıklıkla yaşandığını göstermektedir. Bir başka ifade ile Akdeniz Kıyılarında her 5 yılda 1 ekstrem nemli ya da kurak dönemler yaşanmaktadır. Bu çalışmanın sonuçları, Akdeniz Kıyılarında, bilhassa İlkbahar mevsiminde kuraklık eğiliminin belirgin bir şekilde arttı̆̆ını göstermektedir.

Anahtar Kelimeler: Akdeniz Kıyıları, Ekstrem İklim, Kuraklık, İklim Değişikliği.

\author{
Distribution of Extreme Wet and Dry Seasons (1967-2016) \\ Along Mediterranean Coast, Turkey \\ ${ }^{* 1}$ Mehmet Ali Çelik \\ ${ }^{1}$ Kilis 7 Aralık University, Faculty Of Arts And Science, mehmetalicelikk@gmail.com
}

\begin{abstract}
Climate change is defined as deviation of climatic conditions from average situation for long years. A lot of studies report that there would be an increase in extreme weather events together with climate change. One of regions where would be most affected by climate change in Turkey is Mediterranean Coasts. In this context, it is important to determine extreme climate seasons and to take the required precautions. In this study, seasonal SPI drought analyses within the period of last 50 years including $1967-$ 2016 were carried out. In our study, data belonging to 15-meteorological stations located along Mediterranean Coasts were used. Findings obtained show that extreme climatic conditions are frequently experienced along Mediterranean Coasts. In other words, extreme wet or dry periods are experienced once every five years along Mediterranean Coasts. Results of this study show that drought tendency increased prominently along Mediterranean Coasts during Spring seasons, in particular.
\end{abstract}

Keywords: Mediterranean Coasts, Extreme Climate, Drought, Climate Change

\section{INTRODUCTION}

Five main components, called as atmosphere, hydrosphere, cryosphere, lithosphere and biosphere, constitute life on the Earth, and interaction among these components generates complex system named as global climate system [1, 2]. Due to both natural and anthropogenic reasons, increases occured so many times on global climate system. Climate change is defined as deviation of climatic conditions from average situation for long years (for decades). Extreme weather events have been increasing together with climate change. This situation has been increasing destructrive impacts, such as drought, flood etc., of weather events [3].

It is known that weather events influence a great part of human activities. Particularly in regions where climate 
shows deviations from average, weather events create destructive impact on human activities. For this reason, it is important that scientists could make short-term forecastings on weather events [4].

One of regions where would be most affected by climate change in Turkey is the Mediterranean [5]. A lot of studies reported that high precipitation variability increased extreme climatic conditions in Mediterranean Region [6,7,8]. One of these studies is the study by Türkeş and Tatlı [9]. Türkeş and Tatlı revealed drought situation in total precipitation series in the study which they carried out using data of 96meteorological stations belonging to Turkey. In the study, Standardized Precipitation Index (SPI) method was employed. As a result of the study, $70 \%$ of Turkish precipitations has probability of being normal, but the situation in Mediterranean Regions is different from the Turkish normal. According to results of the study, situations/states of being extreme dry in Mediterranean Region are at the highest level by $20 \%$ in Turkey. As a result of the study, it is emphasized that specifically coastal and terrestrial Mediterranean regions of Turkey would be affected more frequently, and by severe drought events and desertification processes more in the future. In this context, it is important that extreme climate seasons should be determined in Mediterranean Region of Turkey where is situated in a sensitive location in terms of climate change and that the required precautions should be taken. In this study, drought seasons which occured in last 50 years along Mediterranean Coasts of Turkey were determined, and trends of these wet and dry extreme periods were stated.

The article should start with an introduction written in scientific language, putting thoughts together from diverse disciplines combining evidence-based knowledge and logical arguments, conveying views about the aim and purpose of the article. It must address all readers in general. The technical terms, symbols, abbreviations must be defined at the first time when they are used in the article.

\subsection{Study Area}

In general, typical Mediterranean climate that is hot and dry in summers, and warm and rainy in winters is dominant along coast line reaching (rising) up to $1000 \mathrm{~m}$ of Mediterranean Region. On upper parts, Mediterranean mountain climate is dominant, which is cold and snowy in winters, and cool and relatively rainly in summers. Air masses and topographic features have an influence on climate of the region [10,11,12]. As is across Turkey, air masses having influence in summer and winter seasons affect the climate of Mediterranean Region. Tropical air mass (T-Tropical) coming from the Atlantic Ocean and the Sahara becomes effective during summer seasons in Mediterranean Region,. Temperature of the said hot and dry air (cT-continental Tropical) stemming from the Sahara declines relatively and the said air gets moisture while it is passing over the Mediterranean. This air mass being moist (mT-maritime Tropical) creates a misty view. Hot-dry air mass, coming from Arabian deserts sometimes and becoming effective with penetration of the Basra lowpressure (cyclone) into eastern part of the region by expanding, decreases the wet in troposphere and increases the temperature. By the month of November, the region falls under the influence of warm and moist air mass coming from Central Mediterranean in general. Not to mention, frontial activities begins by confrontation/encounter of tropical air with polar air which moves to Central Mediterranean from north direction. In other saying, cold and hot fronts follow one another, and therefore rains occur. Hot and cold weather conditions changing within the day follow each other. Fronts which essentially lead to formation of rains in Mediterranean Region come from over Central Mediterranean and they move from southwestern towards northeastern. Since Taurus Mountains hinder progression of fronts, they (the Taurus mountains) cause fronts to meet with each other. For this reason, southwest-ward /facing slopes of Taurus Mountains receive rain more. As a matter of fact, while southwestward/facing slopes of Geyik Mountains receive the rain over $2000 \mathrm{~mm}$, Mut trough/gulley located in ravin Göksu Valley receives the rain below $400 \mathrm{~mm}$ as it is in the shadow of rain. Frontal movements are quite unsettled/unchanceable and their frequencies often vary by months. Thus, the Mediterranean is the region which has the highest deviation of rainfall. As a matter of fact, amount of precipitation falled in November and December in some years in Antalya city constitutes $25 \%$ of annual total precipitation. In some years, it has been witnessed that the rainfall occured even less in these months. Temperature change is not much along coastal line of Mediterranean Region within the year and temperature difference rises between summer and winter into the inner sides and towards the high lands of Taurus Mountains. Annual average temperature in the region is a bit above $18^{\circ} \mathrm{C}$ along the Mediterranean Coast. Frost events are rarely experienced along the Mediterranean coastal line $[10,11,12]$.

The climate along Mediterranean Coasts are usually subarid. Summers are dry, winters are mild and wet [13]. The purpose of our study is to determine dry periods along Mediterranean Coast where precipitation variability is about $25 \%$ and consequently drought is frequently experienced, and to emphasize drought severity using various indices.

The Mediterranean Region is surrounded by Eagean Region from west, Central Anatolia Region from north, East Anatolia Region from northeast and Southwestern Anatolia Region and Syria from east. Distance as the crow flies (air distance) of the Mediterranean Region in east-west direction is circa $800 \mathrm{~km}$. While sometimes width of the region in north-south direction narrows, it widens sometimes, depending on lying of mountains (Figure 1). 


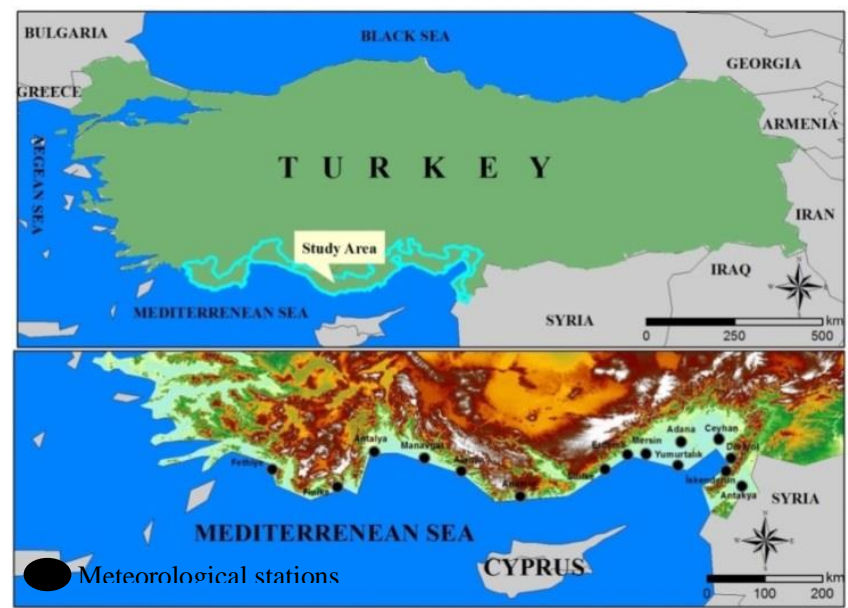

Figure 1. Locations of the study sites (Map of Mediterranean Coast).

\section{DATA-METHOD}

Estimation of extreme wet and dry weather conditions on the basis of moving average of daily precipitation allows to determine the most drastic periods and trends of SPI along Mediterranean Coast (Turkey) in last 50 years. The wet and dry days have been selected from the calculation results of the precipitation moving average.

The study of drought trends is done by analysing the time series of a drought index. A drought Index is typically a single value used for indicating the severity of a drought and is far more useful than raw data in understanding the drought conditions over an area. SPI is a drought index to monitor and quantify Meteorological drought. One of the commonly used tools for detecting changes in climatic and hydrologic time series is trend analysis $[14,15,16,17]$. Trend analysis of SPI time series will reveal the drought trends at particular station. As rainfall is the only input parameter for Meteorological drought analysis, trend analysis of seasonal and intra-seasonal rainfall is essential to detect micro changes in climate change scenario.

The climate data of Mersin were received from the Turkish State Meteorological Service (MGM). Daily and monthly total precipitation and average temperature data and daily maximum and minimum precipitation and temperature data from Mersin, Erdemli, Anamur and Silifke stations cover a period of more than 40 years (Table 1). Thus, meteorological drought indices were established.

Table 1. Data used in the study

\begin{tabular}{|c|c|c|c|}
\hline 1) & Fethiye & $\begin{array}{l}\text { Monthly and daily temperature } \\
\text { and precipitation data (average, } \\
\text { maximum and minimum) }\end{array}$ & $\begin{array}{l}1967- \\
2016\end{array}$ \\
\hline 2) & Finike & $\begin{array}{l}\text { Monthly and daily temperature } \\
\text { and precipitation data (average, } \\
\text { maximum and minimum) }\end{array}$ & $\begin{array}{l}1967- \\
2016\end{array}$ \\
\hline 3) & Antalya & $\begin{array}{l}\text { Monthly and daily temperature } \\
\text { and precipitation data (average, } \\
\text { maximum and minimum) }\end{array}$ & $\begin{array}{l}1967- \\
2016\end{array}$ \\
\hline
\end{tabular}

\begin{tabular}{|c|c|c|c|}
\hline 4) & Manavgat & $\begin{array}{l}\text { Monthly and daily temperature } \\
\text { and precipitation data (average, } \\
\text { maximum and minimum) }\end{array}$ & $\begin{array}{l}1967- \\
2016\end{array}$ \\
\hline 5) & Alanya & $\begin{array}{l}\text { Monthly and daily temperature } \\
\text { and precipitation data (average, } \\
\text { maximum and minimum) }\end{array}$ & $\begin{array}{l}1967- \\
2016\end{array}$ \\
\hline 6) & Anamur & $\begin{array}{l}\text { Monthly and daily temperature } \\
\text { and precipitation data (average, } \\
\text { maximum and minimum) }\end{array}$ & $\begin{array}{l}1967- \\
2016\end{array}$ \\
\hline 7) & Silifke & $\begin{array}{l}\text { Monthly and daily temperature } \\
\text { and precipitation data (average, } \\
\text { maximum and minimum) }\end{array}$ & $\begin{array}{l}1967- \\
2016\end{array}$ \\
\hline 8) & Erdemli & $\begin{array}{l}\text { Monthly and daily temperature } \\
\text { and precipitation data (average, } \\
\text { maximum and minimum) }\end{array}$ & $\begin{array}{l}1967- \\
2016\end{array}$ \\
\hline 9) & Mersin & $\begin{array}{l}\text { Monthly and daily temperature } \\
\text { and precipitation data (average, } \\
\text { maximum and minimum) }\end{array}$ & $\begin{array}{l}1967- \\
2016\end{array}$ \\
\hline 10) & Adana & $\begin{array}{l}\text { Monthly and daily temperature } \\
\text { and precipitation data (average, } \\
\text { maximum and minimum) }\end{array}$ & $\begin{array}{l}1967 \\
2016\end{array}$ \\
\hline 11) & Yumurtalık & $\begin{array}{l}\text { Monthly and daily temperature } \\
\text { and precipitation data (average, } \\
\text { maximum and minimum) }\end{array}$ & $\begin{array}{l}1967- \\
2016\end{array}$ \\
\hline 12) & Ceyhan & $\begin{array}{l}\text { Monthly and daily temperature } \\
\text { and precipitation data (average, } \\
\text { maximum and minimum) }\end{array}$ & $\begin{array}{l}1967- \\
2016\end{array}$ \\
\hline 13) & Dörtyol & $\begin{array}{l}\text { Monthly and daily temperature } \\
\text { and precipitation data (average, } \\
\text { maximum and minimum) }\end{array}$ & $\begin{array}{l}1967- \\
2016\end{array}$ \\
\hline 14) & İskenderun & $\begin{array}{l}\text { Monthly and daily temperature } \\
\text { and precipitation data (average, } \\
\text { maximum and minimum) }\end{array}$ & $\begin{array}{l}1967- \\
2016\end{array}$ \\
\hline 15) & Antakya & $\begin{array}{l}\text { Monthly and daily temperature } \\
\text { and precipitation data (average, } \\
\text { maximum and minimum) }\end{array}$ & $\begin{array}{l}1967- \\
2016\end{array}$ \\
\hline
\end{tabular}

\subsection{Drought Indice}

\subsubsection{Standardized Precipitation Index (SPI)}

SPI is an effective method in determining, evaluating and monitoring droughts and improving a region/a country's abilities or possibilities for drought management and for struggling the drought $[18,19]$. Standardized Precipitation Index method was developed firstly by Mckee et al. [20], converting precipitation parameter to a single numerical value (digitisation) in order to determine the drought of areas showing different climatic characteristics This method is obtained through the following equation (1) by taking the difference of the precipitation $(\mathrm{Xi})$ from the mean $\left(\mathrm{X}_{\mathrm{i}}\right.$ mean) for a particular selected time scale and then dividing by the standard deviation $(\sigma)$. SPI is calculated by this formula [20]:

$$
\mathrm{SPI}=\left(\mathrm{X}_{\mathrm{i}}-\mathrm{X}_{\mathrm{I}}\right) / \sigma
$$

When results obtained are -2 and below, they indicate exceptionally drought conditions, whereas SPI values of 2 and higher show that extremely humidness is dominant in the climate (Table 2). 
Table 2. Classification of the results of the SPI [20].

\begin{tabular}{l|l}
\hline SPI value & Classification \\
\hline $\mathbf{2}$ and higher & Exceptionally Humid \\
\hline $\mathbf{1 . 6 0}$ to 1.90 & Extremely Humid \\
\hline $\mathbf{1 . 3 0}$ to $\mathbf{1 . 5 9}$ & Very Humid \\
\hline 0.80 to 1.29 & Moderately Humid \\
\hline 0.51 to 0.79 & Abnormally Humid \\
\hline 0.50 to $-0,50$ & Normal \\
\hline-0.51 to -0.79 & Abnormally Dry \\
\hline-0.80 to -1.29 & Moderately Dry \\
\hline $\mathbf{- 1 . 3 0}$ to $\mathbf{- 1 . 5 9}$ & Severely Dry \\
\hline $\mathbf{- 1 . 6 0}$ to $\mathbf{- 1 . 9 9}$ & Extremely Dry \\
\hline $\mathbf{- 2}$ and below & Exceptionally Dry \\
\hline
\end{tabular}

Of which above-mentioned SPI classification groups, values of very humid and above $(1.30 \geq)$ and values between severely dry and exceptionally dry $(-1.30 \geq)$ were considered as extreme humid and extreme dry periods.

A drought event is defined here as a period in which the SPI is continuously negative and the SPI reaches a value of -1.0 or less and ends with the positive value of the SPI [21]. The duration (D) is defined by the time between the beginning and end (-ve SPI values); (kontrol ediniz) the magnitude is calculated by the sum of the SPI for every month from the initiation to the end of each drought event and intensity is the ratio between the magnitude and the duration of the event.

\subsection{Trend Test}

The Mann-Kendall test is used for determining monotonic trends and is based on ranks [22]. The purpose of trend analysis is to determine if a series of observations of a random variable is generally increasing or decreasing with time. Even though parametric trend tests are more powerful, non-parametric trend tests are widely used as they require the data be independent and could accommodate outliers in the data [23]. In this study, the non-parametric Mann-Kendall test is used in trend detection of drought along Mediterranean Coast. When significant, the magnitude of the existing trend was estimated with the Sen's Slope Estimator method [22].

The Mann-Kendall statistic $S$ is given as. The MK test statistic and the sign function are calculated using the formula:

$$
S=\sum_{i=1}^{n-1} \sum_{j=i+1}^{n} \operatorname{sgn}\left(x_{j}-x_{i}\right)
$$

Each of the data points xi is taken as a reference point which is compared with the rest of the data point's xj so that,

$$
\operatorname{Sgn}\left(x_{j}-x_{i}\right)=\left\{\begin{array}{c}
+1,>\left(x_{j}-x_{i}\right) \\
0,=\left(x_{j}-x_{i}\right) \\
-1,>\left(x_{j}-x_{i}\right)
\end{array}\right.
$$

where $n$ is the number of data, $x$ is the data point at times $i$ and $\mathrm{j}(\mathrm{j}>\mathrm{i})$. The variance statistic is given as

$$
\operatorname{var}(S)=\left[n(n-1)(2 n+5)-\sum_{i=1}^{m} t_{i} i(i-1)(2 i+5)\right] / 18
$$

Where $t_{i}$ as considered the number of ties up to sample $i$. The test statistics $\mathrm{Zc}$ is computed as

$$
\mathrm{Z}_{\mathrm{c}}=\left\{\begin{array}{l}
\frac{\mathrm{s}-1}{\sqrt{\operatorname{Var}(s)}}, \mathrm{S}>0 \\
0, \mathrm{~S}=0 \\
\frac{\mathrm{s}-1}{\sqrt{\operatorname{Var}(\mathrm{s})}}, \mathrm{S}<0
\end{array}\right.
$$

$\mathrm{Z}_{\mathrm{c}}$ here follows a standard normal distribution. A positive (negative) value of $\mathrm{Zc}$ signifies an upward (downward) trend. The significance level, or a Type I error, $\alpha$, is the probability of rejecting the null hypothesis, when it is true. A significance level $\alpha$ is also utilized for testing either an upward or downward monotonic trend.

\section{RESULTS}

Extreme humid and dry seasons of 15-meteorological stations located along the Coastal Mediterranean were determined. Accordingly, the most extreme humid and dry period was observed at Erdemli station. Frequency of the least extreme humid and dry period was detected at Alanya station.

At Fethiye meteorological station, in last 50 years, 45extreme periods were determined. During fall and winter seasons, frequency of extreme humid and dry conditions is more compared to other seasons. During fall and winter seasons, 28-extreme periods were detected.

At Finike meteorological station located within the provincial borders of Antalya, 48- extreme humid and dry periods were determined. Also in Finike, frequency of the most extreme period is during fall and winter seasons. While there were 15-extreme periods during fall, 14-extreme periods were detected during winter.

Frequency of the most extreme humid and dry period along western coasts of Mediterranean belongs to Antalya and Manavgat stations. 50-extreme periods were determined in last 50 years at Manavgat and Antalya meteorological stations. In other words, extreme season was experienced for approximately every year in Antalya and Manavgat. While detecting 26-extreme humid and dry seasons in last 25 years in Antalya, 22-extreme humid and dry periods were determined in the same years. 
Among meteorological stations located in Western Mediterranean, Alanya is the station which have had the least extreme conditions in climate. 41-times extreme humid and dry periods were detected in last 50 years in Alanya. As is across stations located in Western Mediterranean, also in Alanya, Spring is the period when the most extreme conditions were seen. Frequency of extreme dry and humid periods increased in last 25 years in Alanya. While the frequency of extreme dry and humid seasons was 18 in 25 years through 1967-1991,23-extreme humid and dry periods were determined in 25 years through 1992-2016.

When it comes to middle part of Mediterranean coasts, frequency of extreme period was 45 at Anamur station and 47 at Silifke station. While observing 23-extreme dry and humid periods in last 25 years in Anamur, 25-extreme seasons were detected in the same years in Silifke. The most extreme period along Eastern Mediterranean coasts was seen at Erdemli station. Adana and Dörtyol stations located along Eastern Mediterranean are sections where the least frequency of extreme periods were determined (Table 3 ).

Table 3. Frequency of extreme humid and dry climate occured in last 50 years at stations located along Mediterranean Coast.

\begin{tabular}{|c|c|c|c|}
\hline Station & \multicolumn{3}{|c|}{ Fethiye } \\
\hline Season/Years & $1967-1991$ & $1992-2016$ & Last 50 years \\
\hline Spring & 7 & 3 & 10 \\
\hline Summer & 4 & 3 & 7 \\
\hline Fall & 5 & 9 & 14 \\
\hline Winter & 5 & 9 & 14 \\
\hline Total & $\underline{21}$ & $\underline{24}$ & $\underline{45}$ \\
\hline Station & \multicolumn{3}{|c|}{ Manavgat } \\
\hline Season/Years & $1967-1991$ & 1992-2016 & Last 50 years \\
\hline Spring & 5 & 3 & 8 \\
\hline Summer & 6 & 4 & 10 \\
\hline Fall & 7 & 9 & 16 \\
\hline Winter & 8 & 6 & 16 \\
\hline Total & $\underline{26}$ & 22 & $\underline{50}$ \\
\hline Station & \multicolumn{3}{|c|}{ Silifke } \\
\hline Season/Years & 1967-1991 & 1992-2016 & Last 50 years \\
\hline Spring & 10 & 6 & 16 \\
\hline Summer & 5 & 5 & 10 \\
\hline Fall & 3 & 9 & 12 \\
\hline Winter & 4 & 5 & 9 \\
\hline Total & 22 & 25 & 47 \\
\hline Station & \multicolumn{3}{|c|}{ Yumurtalık } \\
\hline Season/Years & $1967-1991$ & $1992-2016$ & Last 50 years \\
\hline Spring & 5 & 6 & 11 \\
\hline Summer & 7 & 8 & 15 \\
\hline Fall & 5 & 9 & 14 \\
\hline
\end{tabular}

\begin{tabular}{|c|c|c|c|}
\hline Winter & 5 & 5 & 10 \\
\hline Total & $\underline{22}$ & $\underline{28}$ & $\underline{50}$ \\
\hline Station & \multicolumn{3}{|c|}{ Dörtyol } \\
\hline Season/Years & 1967-1991 & $1992-2016$ & Last 50 years \\
\hline Spring & 10 & 3 & 13 \\
\hline Summer & 2 & 6 & 8 \\
\hline Fall & 5 & 7 & 12 \\
\hline Winter & 6 & 5 & 11 \\
\hline Total & 23 & 21 & 44 \\
\hline Station & \multicolumn{3}{|c|}{ Finike } \\
\hline Season/Years & 1967-1991 & $1992-2016$ & Last 50 years \\
\hline Spring & 6 & 2 & 8 \\
\hline Summer & 6 & 5 & 11 \\
\hline Fall & 7 & 8 & 15 \\
\hline Winter & 7 & 7 & 14 \\
\hline Total & $\underline{26}$ & $\underline{22}$ & 48 \\
\hline Station & \multicolumn{3}{|c|}{ Alanya } \\
\hline Season/Years & 1967-1991 & $1992-2016$ & Last 50 years \\
\hline Spring & 4 & 6 & 10 \\
\hline Summer & 3 & 5 & 8 \\
\hline Fall & 8 & 6 & 14 \\
\hline Winter & 3 & 6 & 9 \\
\hline Total & 18 & 23 & 41 \\
\hline Station & \multicolumn{3}{|c|}{ Erdemli } \\
\hline Season/Years & 1967-1991 & $1992-2016$ & Last 50 years \\
\hline Spring & 8 & 8 & 16 \\
\hline Summer & 8 & 6 & 14 \\
\hline Fall & 6 & 9 & 15 \\
\hline Winter & 6 & 4 & 10 \\
\hline Total & $\underline{28}$ & 27 & $\underline{55}$ \\
\hline Station & \multicolumn{3}{|c|}{ Adana } \\
\hline Season/Years & 1967-1991 & $1992-2016$ & Last 50 years \\
\hline Spring & 8 & 4 & 12 \\
\hline Summer & 6 & 5 & 11 \\
\hline Fall & 4 & 6 & 10 \\
\hline Winter & 5 & 6 & 11 \\
\hline Total & $\underline{23}$ & $\underline{21}$ & $\underline{44}$ \\
\hline Station & \multicolumn{3}{|c|}{ İskenderun } \\
\hline Season/Years & 1967-1991 & $1992-2016$ & Last 50 years \\
\hline Spring & 6 & 7 & 13 \\
\hline Summer & 6 & 6 & 12 \\
\hline Fall & 6 & 3 & 9 \\
\hline Winter & 5 & 6 & 11 \\
\hline Total & $\underline{23}$ & $\underline{22}$ & 45 \\
\hline Station & \multicolumn{3}{|c|}{ Antalya } \\
\hline Season/Years & $1967-1991$ & $1992-2016$ & Last 50 years \\
\hline
\end{tabular}




\begin{tabular}{|c|c|c|c|}
\hline Spring & 4 & 7 & 11 \\
\hline Summer & 7 & 6 & 13 \\
\hline Fall & 7 & 6 & 13 \\
\hline Winter & 6 & 7 & 13 \\
\hline Total & $\underline{24}$ & $\underline{26}$ & $\underline{50}$ \\
\hline Station & \multicolumn{3}{|c|}{ Anamur } \\
\hline Season/Years & $1967-1991$ & $1992-2016$ & Last 50 years \\
\hline Spring & 7 & 7 & 14 \\
\hline Summer & 3 & 6 & 9 \\
\hline Fall & 6 & 7 & 13 \\
\hline Winter & 6 & 3 & 9 \\
\hline Total & $\underline{22}$ & $\underline{23}$ & $\underline{45}$ \\
\hline Station & \multicolumn{3}{|c|}{ Mersin } \\
\hline Season/Years & $1967-1991$ & $1992-2016$ & Last 50 years \\
\hline Spring & 6 & 6 & 12 \\
\hline Summer & 9 & 6 & 15 \\
\hline Fall & 5 & 6 & 11 \\
\hline Winter & 5 & 5 & 10 \\
\hline Total & $\underline{25}$ & $\underline{\underline{23}}$ & $\underline{48}$ \\
\hline Station & \multicolumn{3}{|c|}{ Ceyhan } \\
\hline Season/Years & $1967-1991$ & $1992-2016$ & Last 50 years \\
\hline Spring & 7 & 7 & 14 \\
\hline Summer & 6 & 5 & 11 \\
\hline Fall & 7 & 9 & 16 \\
\hline Winter & 5 & 5 & 10 \\
\hline Total & $\underline{25}$ & $\underline{26}$ & $\underline{51}$ \\
\hline Station & \multicolumn{3}{|c|}{ Antakya } \\
\hline Season/Years & 1967-1991 & $1992-2016$ & Last 50 years \\
\hline Spring & 7 & 8 & 15 \\
\hline Summer & 5 & 3 & 8 \\
\hline Fall & 3 & 6 & 9 \\
\hline Winter & 5 & 9 & 14 \\
\hline Total & $\underline{\underline{20}}$ & $\underline{\underline{26}}$ & $\underline{46}$ \\
\hline
\end{tabular}

According to studies done, it is foreseen that particularly winter precipitations would decrease in the future [24]. In the study which was done for Akdeniz Basin, Türkeş et al., emphasized that amount of winter precipitations decreased. It can be said decrease in winter precipitations is related to the decrease in transition frequency of fronts which pass over Mediterranean Basin and to the fact that transition way skidded toward northern slightly, depending on global warming [25]. That winter precipitations constituting a great part of annual precipitation in Mediterranean Basin showed a tendency to decrease confronts us as a fact which should be taken into consideration that basin product pattern being shaped according to this regime will be able to undergo an

important change due to temperature and precipitation conditions changing in the future [26].

Another study carried out revealed the result that droughts in Mediterranean had a tendency to increase [7]. Ölgen, in study which aimed to reveal spatial distribution of precipitation variability belonging to long years in Turkey, stated that, however it had little differences in itself, precipitation variability increased in a way that could be considered regular from north toward south and that, owing to changefulnesses in precipitations belonging to long years, droughts were being experienced frequently Mediterranean Region at which coefficient of variation was more than $25 \%$.

Table 4. Z values from Mann-Kendall tests.

\begin{tabular}{lllll}
\hline & \multicolumn{2}{c}{ Spring } & \multicolumn{2}{c}{ Summer } \\
\cline { 2 - 5 } Station/ & $\mathbf{1 9 6 7 -}$ & $\mathbf{1 9 9 2 -}$ & $\mathbf{1 9 6 7 -}$ & $\mathbf{1 9 9 2 -}$ \\
Years & $\mathbf{1 9 9 1}$ & $\mathbf{2 0 1 6}$ & $\mathbf{1 9 9 1}$ & $\mathbf{2 0 1 6}$ \\
\hline Fethiye & $-0,62$ & 0,00 & $-1,55$ & 1,13 \\
\hline Finike & $-1,15$ & $-0,45$ & $-0,84$ & $-0,79$ \\
\hline Antalya & $-0,48$ & $-0,95$ & $-0,47$ & 0,65 \\
\hline Manavgat & $-0,69$ & $\mathbf{- 2 , 2 9}$ & $-0,97$ & 0,29 \\
\hline Alanya & $-0,87$ & 0,00 & 0,97 & $-0,48$ \\
\hline Anamur & $-1,60$ & $-0,36$ & 0,35 & $-0,13$ \\
\hline Silifke & $-0,72$ & $-0,12$ & $-1,13$ & $-0,92$ \\
\hline Erdemli & $-1,31$ & $-1,51$ & 0,34 & $-0,65$ \\
\hline Mersin & $-0,05$ & $-0,05$ & $-0,14$ & $-1,02$ \\
\hline Yumurtal1k & $-0,98$ & $\mathbf{- 1 , 9 7}$ & 0,26 & $-0,61$ \\
\hline Adana & $-0,26$ & 0,45 & 0,53 & 0,02 \\
\hline Ceyhan & $-0,12$ & $-0,92$ & $-0,65$ & $-1,03$ \\
\hline Dörtyol & $-0,63$ & $-1,41$ & 0,15 & 0,62 \\
\hline İskenderun & $-1,37$ & $-0,72$ & 0,34 & 0,50 \\
\hline Antakya & $-0,73$ & $-0,83$ & $-0,75$ & 0,28 \\
\hline
\end{tabular}

\begin{tabular}{lllll}
\multirow{2}{*}{$\begin{array}{l}\text { Station/ } \\
\text { Years }\end{array}$} & \multicolumn{3}{c}{ Fall } & \multicolumn{2}{c}{ Winter } \\
\cline { 2 - 5 } Fethiye & $\mathbf{1 9 6 7 -}$ & $\mathbf{1 9 9 2 -}$ & $\mathbf{1 9 6 7 -}$ & $\mathbf{1 9 9 2 -}$ \\
\hline Finike & $-0,93$ & $-0,17$ & $-1,32$ & $\mathbf{1 , 6 9}$ \\
\hline Antalya & $-0,59$ & 0,27 & $-1,43$ & 1,04 \\
\hline Manavgat & $-0,75$ & $-0,81$ & $-1,51$ & $-0,65$ \\
\hline Alanya & 0,55 & 0,19 & $-1,18$ & 0,70 \\
\hline Anamur & 0,02 & 0,10 & $-0,92$ & $-0,71$ \\
\hline Silifke & $-0,69$ & $-0,63$ & $-1,06$ & 0,72 \\
\hline Erdemli & 0,51 & $-0,43$ & $-0,78$ & $-0,25$ \\
\hline Mersin & $-0,25$ & $-0,78$ & $-0,72$ & $-0,85$ \\
\hline Yumurtal1k & $-0,12$ & 0,34 & $-0,23$ & 0,24 \\
\hline Adana & $\mathbf{1 , 7 5}$ & $\mathbf{- 1 , 7 9}$ & $-1,12$ & 0,00 \\
\hline Ceyhan & 0,30 & $-1,14$ & $-0,77$ & $-1,06$ \\
\hline Dörtyol & 1,45 & $-0,93$ & $-0,78$ & $-0,41$ \\
\hline İskenderun & $\mathbf{1 , 9 9}$ & 0,25 & $-0,96$ & 0,50 \\
\hline Antakya & $\mathbf{1 , 8 8}$ & 0,59 & $-0,64$ & 0,81 \\
\hline & 1,26 & 0,45 & $-0,55$ & 0,00 \\
\hline
\end{tabular}


Studies carried out give the conclusion that drought increased and winter precipitations decreased. In this chapter of the study, Mann-Kendall test was applied to results of seasonal drought analysis. Thus, drought tendency of 15meteorological stations located along Mediterranean coasts of Turkey was determined. Results obtained give the conclusion that drought tendency showed statistically meaningful changes during spring seasons at some stations located along Mediterranean Coasts. These are Manavgat and Yumurtalık stations. During fall seasons, humidity trend showed statistically meaningful increases at Yumurtalık, Dörtyol and İskenderun stations. Increases in humidity trend of the mentioned stations were seen through the years of 1967-1991. No statistically meaningful increases were detected during fall seasons (Table 4).

When generally evaluated, drought tendency to increase strikes along Mediterranean Region in general. When MannKendall test was applied to the drought analysis results of last 50 years, it is seen that drought increased in all months out of fall seasons. These increases occured in drought severity were not statistically meaningful. In last 50 years, the most meaningful increase trend happened during Spring seasons (Table 5).

Table 5. Z values from Mann-Kendall tests for Mediterranean Coast (1967-2016).

\begin{tabular}{llcl}
\hline Season & $\begin{array}{c}\text { Z Value } \\
(1967-1991)\end{array}$ & $\begin{array}{c}\text { Z Value } \\
(1992-2016)\end{array}$ & $\begin{array}{l}\text { Z Value } \\
\text { (last 50 } \\
\text { years })\end{array}$ \\
\hline Winter & $-1,43$ & 0,23 & $-0,40$ \\
\hline Spring & $-1,10$ & $-1,03$ & $-0,64$ \\
\hline Summer & $-0,56$ & $-0,26$ & $-0,23$ \\
\hline Fall & 0,37 & $-0,61$ & 0,10 \\
\hline
\end{tabular}

According to data of Fethiye meteorological station for Spring seasons, extreme drought periods in last 50 years were observed. Spring periods of 1973, 1985, 1986, 1989 and 2010 were extreme dry. The years of 1980, 1987, 1988, 2003 and 2009 were extreme humid periods. It is seen that extreme humid and dry conditions were experienced in Fethiye during the spring seasons of five years through 19851989 , in particular. Spring SPI trend of Fethiye showed tendency to decrease through the years of 1967-1991. SPI trend followed a normal course through the years of 19922016 including last 25 years. Results of SPI analysis for summer seasons in Fethiye showed contrast between the years of 1967-1991 and of 1992-2016. During 25-year period including 1967-1991, SPI trend showed a negative trend. According to the 25-year trend including 1992-2016, SPI tendency is in positive directional. In other words, while humidity increased during summer seasons of last 25 years, drought showed a tendency to increase during the period through the years of 1967-1991.

Tendency of SPI analysis during fall seasons at Fethiye station was examined. Accordingly, it is seen that drought increased in the trend of Fall seasons through the years of 1967-1991. It is seen that results of SPI analysis for Fall seasons were in the normal course during the period of years of 1992-2016. It is seen frequency of extreme humid and dry periods was more during fall seasons of last 25 years.

Results of SPI analysis showed contrast during Winter seasons between 1967-1991 and 1992-2016. SPI trend showed tendency to increase in last 25 years. Humidity increased through the years of 1992-2016. Drought increased according to SPI trend through 1967-1991.

SPI analysis was applied to data belonging to Finike station located in western part of Mediterranean coasts. Tendency of SPI results was analysed. Accordingly, there was an increase tendency in the drought of Spring seasons of the 25-year period through 1967-1991. Also an increase was in question during Spring seasons of last 25-year period. Extreme droughts were seen during the springs of the years of 1973, 1986 and 2010. On the other hand, during the springs period of the years of 1988 and 2003, extreme humid conditions were dominant.

SPI tendency for Summer seasons of last 50 years showed that drought increased. But, there was a great number of extreme humid periods during Summer seasons. Extreme humid conditions were seen during Summer seasons of the years of 1982, 1992 and 2003.

Extreme humid and dry periods happened during Fall seasons of last 50 years. No extreme dry periods were observed in last 17 years. According to SPI results of Finike for Fall seasons, extreme humid periods were experienced six times in last 17 years. Humidity increased according to SPI trend of Fenike for Winter seasons of last 25 years. During the 25-year period through 1967-1991, it is seen that dry conditions were in tendency to increase.

SPI analyses for seasons of Spring, Summer, Fall and Winter were performed using last 50 years of data belonging to Antalya meteorological station. In this chapter of the study, tendency analysis was applied to SPI results. It is seen that drought tendency generally increased in Antalya. Specifially during Fall period, it is seen that drought tendency was more apparent. Situations of drought and humidity for Spring period were analysed in two periods being the years of 19671991 and of 1992-2016. Accordingly, it is seen that frequency of extreme Spring periods increased in last 25 years. The year 2003 became the humidest Spring period of last 50 years.

When drought tendency for Summer seasons of last 50 years has been considered, it strikes (attracts attention) that there were a lot of extreme humid and dry periods. Accordingly, the year 2011 became the humidest Summer season of last 50 years. The driest Summer season of last 50 years was the year 2013. When drought trend for Winter seasons of last 50 years in Antalya has been examined, it is seen that drought tendency increased. The driest Winter 
season of last 50 years was experienced in 2000. The year 1969 was the humidest Winter period of last 50 years.

In last 50-year SPI trend of Manavgat, it is seen that drought tendency increased in general. Particularly during last 25year period of Spring seasons and during Summer seasons through the years of 1967-1991, drought conditions were observed more clearly. In Manavgat, the driest Spring season of last 50 years was experienced in 2016. On the other hand, the Summer season of the years of 1987-1988 strikes as the humidest period.

When SPI results for Fall period of last 50 years have been examined, there is no trend of very clear increase or decrease. Besides this, SPI values during Fall period of some years showed an increase and a decrease suddenly. In Manavgat, the year 1968 became the humidest Fall period of last 50 years. Fall season of the year 1968 was observed as a humid period not only in Manavgat but also along all Mediterranean Coasts. The years of 2006-2007 correspond to the driest Winter season of last 50 years. During the period through the years of 2009-2013, it is seen that Winter season contained humid characteristics.

There was an overall drought tendency in SPI values during all periods, out of Summer seasons, of the years of 19671991. Humidity increased during Summer period of 19671991. On the other hand, during Summer period of last 25 years, it is seen that dry conditions increased.

There was a strong increase in drought tendency during Spring period of 1967-1991 in Anamur. The years of 1989 and 2004 were the driest Spring periods of last 50 years. An increase was observed in humid conditions during Summer seasons of last 50 years. Summer seasons of 1981 and 1982 were the humidest periods of last 50 years in Anamur.

There was no considerable increase or decrease in last 50year SPI trend of Winter seasons, but it is seen that climate was extreme humid during some periods and extreme dry during some periods. As it was along all Mediterranean Coasts, Winter season of 1973-1974 was extreme dry period in Anamur, too. On the other hand, Winter seasons of 1978, 1981 and 2012 were extremely humid. Summer season was experienced seventeen times in last 50 years in Silifke. Summer season was neither dry nor humid, but it was in normal course in 16 ones of last 50 years. Although drought tendency increased slightly during Summer seasons, extreme humid conditions were seen during some periods. The year 1982 became the humidiest Summer season of last 50 years. The year 1990 was the driest Spring season of last 50 years in Silifke. Spring season of the year 1990 was dry not only in Silifke but also across Mediterranean coasts. Winter season of 1973 happened as a dry period both in Silifke and across Mediterranean coasts. The years of 1973 and 2016 were the driest Winter seasons of last 50 years. The year 2016 was dry not only in Silifke but also across Mediterranean coasts. 2002 was detected as the humidest Winter season of last 50 years.
It is seen that extreme humid and dry periods increased during Fall seasons of last 25 years in Silifke. While 12extreme humid and dry periods were experienced in last 50 years, of which 9 were seen in last 25 years. Fall period of the year 1993 was very severely dry whereas extreme humid Fall was experienced in 1994. While Fall period of 1999 was very severely dry, those of 2000 and 2001 were very humid.

Tendency analysis was applied to SPI analysis of data belonging to Erdemli station. Findings obtained are toward that drought tendency increased during Spring seasons. Especially, the years of 1973 and 2007 were the driest Spring period of last 50 years.

When SPI tendency for Summer seasons of last 50 years has been examined, extreme humid and dry periods attract the attention. The years of 1978, 1990 and 1998 were the driest Summer seasons of last 50 years. The year 2012 became the humidest Summer season of last 50 years.

There are SPI tendencies striking during Fall seasons at Erdemli station. It is seen dry conditions increased during Fall seasons of last 25 years, in particular. Significant dry periods attract the attention in last 25 years. During this period of time (25 years), extreme dry periods were experienced 5 times. The years of 1993, 1999, 2003, 2010 and 2016 were Fall periods when the climate was very severely dry. When SPI values of last 25 years have been evaluated, it is seen that a lot of severely droughts were experienced in every 5 years.

Seasonal drought analysis of last 50 years in Mersin was carried out. There are years in which the climate showed extreme humid and dry conditions during all seasons. Significant humid and dry periods were experienced during Spring periods of last 50 years. The humidest Spring season of last 50 years was seen in 1967 . The year 1989 became the driest Spring period of last 50 years. 1989 was detected as a dry spring period across Mediterranean Coasts. When last 25-year SPI trend has been examined, it is seen an overall aridification tendency. Summer periods of 1994 and 2004 happened as extremely dry. During Winter seasons, 4 years through the years of 1971-1974 strike as a extremely dry period.

Result of seasonal SPI analysis belonging to Yumurtalık station was evaluated. Accordingly, Winter season of the years of 1972-1973 was a extremely dry period. Winter season of 2016 became the driest period in last years. On the other hand, Winter season of 1978 was exceptionally humid. When SPI trend for Fall seasons has been examined, it is seen that the period through the years of 2010-2016 was a extremely dry period. When SPI trend for Summer seasons at Yumurtalık station has been examined, extreme humid and dry periods attract the attention. While Summer period of 1980 was extremely dry, Summer season of 1997 was extreme humid. 
SPI analysis for Winter seasons at Adana station was evaluated. The years of 1973 and 2014 strike as extreme dry periods, belonging to Winter periods of Adana. Winter periods of these years were a extremely dry along the whole of Mediterrranean Coasts, as well. During Winter seasons, it is seen that drought tendency increased, particularly during the period of last 25 years. During Summer seasons in Adana, it is seen humidity increased through the years of 1967-1991. Climatic conditions were extremely humid during Summer season of 1981. An overall drought tendency was dominant during Fall periods of last 25 years.

SPI analysis was applied to Ceyhan station located in East Mediterranean Sub-region (Division) of Mediterranean Region. SPI trend of last 50-year period was analyzed in seasonal periods. Last 50-year trend of Ceyhun station, belonging to Summer seasons, showed that there was an overall aridification. During Winter season, aridification tendency strikes in last 25 years. While SPI trend for Fall seasons showed humid tendencies through the years of 1967 1991, aridification tendency drew the attention in last 25 years. At Ceyhan station, the year 1993 became the driest Fall season of last 50 years. 1991 was the driest Summer period of last 50 years. Period through the years of 19711973 corresponds to the driest Winter period of last 50 years.

When SPI trend for Dörtyol station has been analyzed, it is seen that humidity increased during Fall seasons of 19671991. There was an overall aridification tendency during Spring seasons. The Climate was in normal course during seasons of Summer and Winter. There was no overall tendency to increase or decrease during these seasons. Extreme dry periods attract the attention in some years. Spring periods of 1993 and 2012 were extremely dry. Summer seasons of 1982, 2004 and 2012 correspond to extreme dry period. An overall humidity situation was dominant during Fall seasons. When SPI trend for Fall seasons of last 50 years has been examined, there is no extreme dry period except the year 1993. There were extreme dry years during Winter seasons of 1967-2016. The years of 1972, 1973, 2005 and 2014 were extreme dry Winter seasons.

While SPI trend of İskenderun station showed generally drought tendency, it was of humidity during some periods. For example, Drought increased during Spring periods of last 50 years at İskenderun station. It strikes that humid conditions were in tendency to increase during Fall seasons of last 50 years including 1967-2016. There was no tendency to increase or decrease in drought or humidity during Summer seasons. İskenderun station showed normal course during Summer period of last 50 years. Tendency of statisticially insignificant humidity was dominant during Winter seasons of last 25 years including 1992-2016.

As is at other stations located along Mediterranean Coasts, it is seen that dry tendency increased during Spring periods at Antakya station, too. It is seen that drought became more apparent during 25-year period through the years of 1967-
1991, in particular. In addition to this, it is seen that there was also a drought tendency during Summer seasons of 1967-1991 at Antakya station. Situation of the increased humidity attracts the attention during Fall seasons of 19671991.

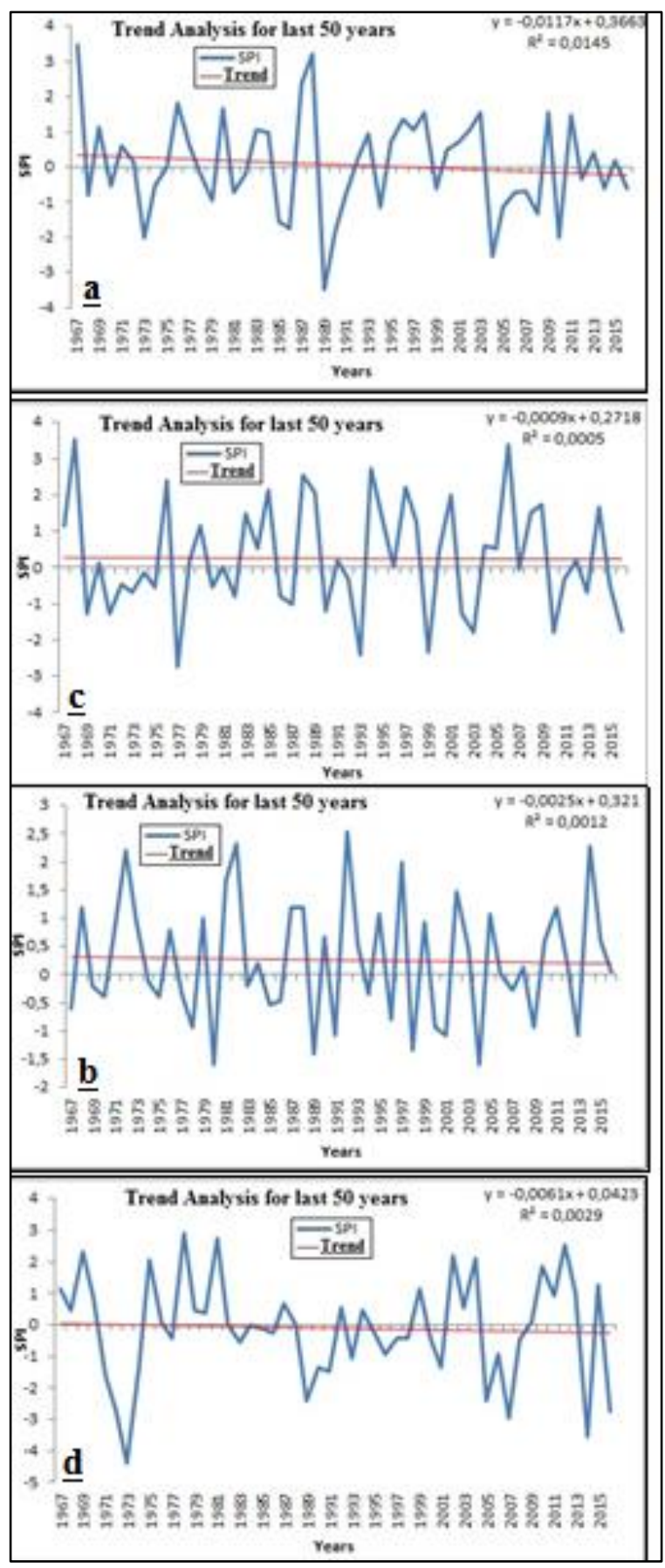

Figure 2. The trend of last 50-year SPI along Mediterranean Coast. (a:spring, b: summer, c:fall, $\mathrm{d}$ :winter).

SPI trend for Mediterranean Coasts-wide, including 19672016, was examined. Accordingly, it is seen that drought tendency increased prominently during Spring seasons. In other words, drought has increased during Spring seasons in 
last 50 years along Mediterranean Coasts. Another issue striking for Mediterranean Coast is that a lot of extreme dry and humid periods were experienced. For example, it is seen that Winter season was dry during the period through 19711973. Besides this, Winter season happened as extremely dry during the period through 2005-2008 along Mediterranean Coasts (Figure 2).

\section{CONCLUSION}

The Mediterranean Region is among important vegetation zones of Turkey and contains fertile farmlands. In our study, seasonal SPI drought analysis was applied to 15meteorological stations located along the Coastal Mediterranean. Thus, extreme dry and humid seasons of last 50 years along Mediterranean Coasts leading sensitive sections of Turkey about climate change were determined. Drought-related studies should focus on the Mediterranean Region. Because this region is faced with major problems related to drought. It is both vitally important and very difficult to identify the severity and duration of drought in advance. Thus, studies on drought should develop facilitating methods for determination of drought severity and early detection of dry periods.

Results obtained show that extreme humid and dry periods are experienced frequently along Mediterranean Coasts of Turkey. Along Coastal Mediterranean receiving a great part of precipitations during Winter season, droughts which are experienced during this period affect food supply, wetlands, fill/fullness amount/rate of dams, agricultural activities negatively. In this context, it is important that dry and humid situations along Mediterranean Coasts be forecasted and predetermined and the required precautions be taken. For example, it is seen that Winter season was dry during 3-year period through the years of 1971-1973 and the period through 2005-2008. There were extreme droughts during a lot of periods as such.

\section{REFERENCES}

[1] Türkeş, M. (2010). Klimatoloji ve Meteoroloji. Birinci Baskı, Kriter Yayınevi - Yayın No. 63, Fiziki Coğrafya Serisi No. 1, ISBN: 978-605-4613-26-7, 650 + XXII pages, İstanbul.

[2] Kızılelma, Y., Çelik, M. A., Karabulut, M., (2015), İç Anadolu Bölgesinde sıcaklık ve yağışların trend analizi, Türk Coğrafya Dergisi, 64, pp. 1-10.

[3] Türkeş, M. (2012). Türkiye'de Gözlenen ve Öngörülen İklim Değişikliği, Kuraklık ve Çölleşme. Ankara Üniversitesi Çevrebilimleri Dergisi 4(2), pp. 1-32.

[4] Türkeş, M. (2001). Hava, İklim, Şiddetli Hava Olayları ve Küresel Isınma. İçinde: T.C. Başbakanlık Devlet Meteoroloji İşleri Genel Müdürlüğü 2000 Yılı Seminerleri, Teknik Sunumlar, Seminerler Dizisi 1: 187-205, Meteoroloji Genel Müdürlüğü: Ankara.

[5] Sütgibi, S. (2015) Büyük Menderes Havzasının Sıcaklık, Yağış Ve Akım Değerlerindeki Değişimler Ve Eğilimler. Marmara Coğrafya Dergisi 31, Ocak, 398-414.
[6] Xoplaki, E., Luterbacher, J., \& Gonzales-Roucho, J. F. (2006). Mediterranean summer temperature and winter precipitation, large-scale dynamics, trends. Nuovo Cimento della Societa Italiana di Fisica. C, Geophysics and Space Physics, 29(1), 45-54.

[7] Ölgen, K. (2010). “Türkiye'de Y1llık ve Mevsimsel Yağış Değişkenliğinin Alansal Dağılım”, Ege Coğrafya Dergisi, 19(1), pp. 85-95.

[8] Erlat, E. and Türkeş, M. (2013). Observed changes and trends in numbers of summer and tropical days, and the 2010 hot summer in Turkey. International Journal of Climatology, 33(8): 1898-1908.

[9] Türkeş, M. ve Tatlı, H. (2008). “Türkiye'de kuraklık olasılıklarının standartlaştırılmış yağış indisi (SPI) Kullanılarak Saptanması Ve İklimsel Değişkenlik Açısından Değerlendirilmesi", Ormanlar Sempozyumu , Bildiriler Kitab1 (Ed., Ünal Akkemik), ss. 55-62. İÜ Orman Fak, 1314 Aralık 2007, Bahçeköy - İstanbul.

[10] Koçman, A. 1993. Türkiye İklimi, EÜ Basımevi, İzmir. [11] Atalay, İ. 2002. Türkiye'nin Ekolojik Bölgeleri, Meta Basımevi, İzmir.

[12] Atalay, İ. 2003. Türkiye Bölgesel Coğrafyası, İnkılâp Kitabevi, İstanbul.

[13] Tavşanoğlu, Ç., \& Gürkan, B. (2004). Akdeniz havzasında bitkilerin kuraklık ve yangına uyumları. Ot Sistematik Botanik Dergisi, 11(1), 119-132.

[14] Li, W., Fu, R., Juarez, R. I. N., \& Fernandes, K. (2008). Observed change of the standardized precipitation index, its potential cause and implications to future climate change in the Amazon region. Philosophical Transactions of the Royal Society of London B: Biological Sciences, 363(1498), 17671772.

[15] Martínez, B.,\& Gilabert, M. A. (2009). Vegetation dynamics from NDVI time series analysis using the wavelet transform. Remote Sensing of Environment, 113(9), 18231842.

[16] Kizılelma, Y., Karabulut, M., (2016). Yozgat ve Çevresinde Kuraklık Analizi, Uluslararası Bozok Sempozyumu, 5-7 Mayıs, Bildiriler Kitabı, Cilt:4, Sayfa: 242-251, Bozok Üniversitesi, Yozgat.

[17] Çelik, M. A.,\& Karabulut, M. (2017). Uydu Tabanlı Kuraklık İndisi (SVI) Kullanılarak Yarı Kurak Akdeniz İkliminde (Kilis) Buğday Bitkisinin Kurak Koşullara Verdiği Tepkinin İncelenmesi. Manisa Celal Bayar Üniversitesi Sosyal Bilimler Dergisi, 15(1), 111-130.

[18] Türkeş, M., Akgündüz, A. S., Demirörs, Z. (2009). "Palmer Kuraklık İndisi'ne göre İç Anadolu Bölgesi'nin Konya Bölümü 'ndeki kurak dönemler ve kuraklık Şiddeti”. Coğrafi Bilimler Dergisi 7, pp. 129-144.

[19] Karabulut, M. (2015). Drought analysis in AntakyaKahramanmaraş Graben, Turkey. Journal of Arid Land, 7(6), 741-754.

[20] McKee, T. B., Doesken, N. J., \& Kleist, J. (1993). The relationship of drought frequency and duration to time scales. In Proceedings of the 8th Conference on Applied Climatology (Vol. 17, No. 22, pp. 179-183). Boston, MA: American Meteorological Society. 
[21] Paulo, A. A. \& Pereira, L. S. (2006). Drought Concepts and Characterization. Water International, 31, pp. 37-49.

[22] Helsel, D. R. \& Hirsch, R. M. (2002). Statistical Methods in Water Resources Techniques of Water Resources Investigations. U.S. Geological Survey.

[23] Tabari, H., Marofi, S., Aeini, A., Talaee, P. H. \& Mohammadi, K. (2011). Trend analysis of reference evapotranspiration in the western half of Iran. Agricultural and Forest Meteorology, 151, pp. 128-136.

[24] Türkeş, M., Koç, T. ve Sarış, F. (2007). “Türkiye'nin Yağış Toplamı ve Yoğunluğu Dizilerindeki Değişikliklerin ve Eğilimlerin Zamansal ve Alansal Çözümlemesi”, Coğrafi Bilimler Dergisi, 5(1), pp. 57-73.

[26] Ramos, M.C. (2001). "Rainfall distribution patterns and their change over time in a Mediterranean area", Theoretical and Applied Climatology, 69, pp. 163-170. 